\title{
Course Teaching System Construction and Practice Based on OBE Idea under "Internet + " Background - Case Study of Hydraulic and Hydropower Engineering
}

\author{
Yun Bao \\ College of Water Conservancy and Hydropower Engineering, Hohai University, Nanjing, 210098, China
}

Keywords: OBE, Hydraulic and Hydropower Engineering major, Course teaching system, Blended teahcing.

\begin{abstract}
As an advanced educational concept, outcome-based education (OBE) has been proven to be highly effective in the aspect of cultivating engineering talents. First of all, the features of OBE-based teahcing and traditional teahcing are compared in this paper. Then, this paper proposes that only when blended teahcing activities are carried out, the core of OBE idea - "stuent-oriented" and "continuous improvement" can bre ally achieved at the teahcing level. after practical exploraiton for many years, " one body with two wings" course teaching system conception for Hydraulic and Hydropower Engineering major based on OBE teaching concept is proposed under the background of internet information technology. The course teaching system design of Hydraulic and Hydropower Engineering major in a university is taken for example.
\end{abstract}

\section{Introduction}

China Association for Science and Technology was accepted as the 18th full member of Washington Accord on international engineering alliance conference convened in Kuala Lumpur on June 2, 2016. This means bachlor's dergee of engineering major ceritified by CEEAA under China Association for Science and Technology will gain the recognition of all full mmebers of Washington Accord. China formally joined Washington Accord, which will promote China to train engineers according to international standards and improve cultivation quality of engineering talents. It is the foundation and key for facilitating international mutual recognition of Chinese engineer qualification and has important significance for Chinese engineering technology field to cope with international competition and go global. ${ }^{[1]}$

\section{Concept of OBE and teaching based on OBE idea}

\section{Concept}

OBE can also be called goal-oriented education or demand-oriented education. Its thought was proposed by William G. Spady et al. in 1980s. In 1994, Spady ssytemtically expounded the concept, definition and composition of OBE in his book Outcome-based Education: Important Dispute and Answer $^{[1]}$. Later, the educational idea of OBE was gradually recognized and generalized by American education circle. This also profoundly influences American engineering field. Since Accreditation Board for Engineering and Technology issued and implemnted OBE-based EC2000 (Engineering Criteria 2000) certification standards, most member states (or regions) of Washington Accord have adopted OBE-based certification standards. the criteria deem student's performance as evaluaiton basis of teaching result and reagrd promotion of continuous major improvement as the ultimate goal of certification ${ }^{[2]}$.

OBE owns three core ideas ${ }^{[3]}$. The first one is student-centered. All teaching activities focus on students' top outcome. The second one is outcome-oriented inverse design. The third one is 
continuous improvement in the education process. It contains three levels: 1) top-level design training program; 2) course teaching content; 3) specific teaching and learning links.

\section{Difference between OBE-based teaching and conventional teaching}

Different teaching ideas will inevitably bring different teaching method, teaching design and teaching process, and change students' learning behaviors and teachers' teaching behaviors. At the beginning of the 20th century, American philosopher and educator Dewey first put forward "child centralism" and indicated the defects of traditional education. In his opinion, "various education measures should focus on children". In the middle of the 20th century, influenced by Dewey, Rogers proposed "student centered" teaching thought. He advocated humanistic, supportive and constructive classroom climate. He firmly believed that for teaching, good relations between students and teachers and classroom climate are more important than nay method and technique ${ }^{[4]}$.

From the teaching level, teacher-centered idea mostly considers the function of teachers in each teaching link, including improvement of teaching quality and courseware PPT quality. Teaching is often one-way. Besides, the idea stresses the authority of teachers and values knowledge transfer, but rarely takes into account of students' learning situation. It lacks or almost has no help for the students falling behind. Students learn passively, and lack active exploration spirit and critical thinking. For student-centered idea, students' feeling and needs should be known in the teaching design, and it values students' learning effect and timely feedback. Meanwhile, teachers will adjust teaching content and method. The teaching is two-way. Teachers regard them as a guide and emphasize knowledge absorption and internalization. Teachers take all kinds of measures to know students' state in the learning process, consider students' differences, really teach students in accordance with their aptitudes and give sufficient attention to and respect of the students falling behind. Students' learning is active. Students are encouraged to deeply study and cultivate critical thinking. Under the student-centered idea, teachers certainly think a lot of exchanges with students and will actively seek the method and chance to communicate with students.

OBE also stresses "student centered". All teaching designs and teaching goals focus on students' learning results ${ }^{[5]}$. Spady defined OBE as follows: clearly pay attention to every event in the educaiton system, and focus on a fundamental goal - let all students gain success when the learning activity ends. This means there should be a clear planning for important things that students can do, and then course teaching evaluation should be organized. Meanwhile, it is required to make sure student-centered idea is implemnted ${ }^{[6]}$.

\section{Course system, teaching and evaluaiton design under the background of modern information technology}

\section{Effects of interent + and communication information technology}

The rapid development of Internet + and communication information technology has led to transformative effect on all walks of life, including each level of higher education. Under such background, course teaching system design for Hydraulic and Hydropower Engineering major should not ignore the huge effect of online course and the teaching mode based on online course and intelligent terminal in teaching reform. OBE embodies student-centered idea and stresses students' final outcome, inverse design course, teaching mode and evaluation system. In particular, teaching design and teaching evaluation must reflect students' learning process. Only when teachers know students' learning process enough can students' individual development and teachers' individual guidance be achieved. Meanwhile, the goals of making everyone succeed and overall improving knowledge, ability and quality can be achieved.

Traditional teaching mode has congenital disadvantage

Under conventional teaching mode, there is a realistic problem, no matter how the teaching content is arranged. Among science and engineering majors, multiple courses and few credits have been a trend, while teaching contents increase. Under such background, students and teachers lack 
exchange, and one-way knowledge transfer is in classroom. In traditional classroom, question asking, discussion and quiz are carried out, but teachers fail to go into them deeply. Teachers do not know students comprehensively, and lack concern about the students falling behind. It is hard to achieve the goal of teaching students in accordance with their aptitudes. The student-centered teaching idea has the limitations of teaching mode, teaching evaluation and student-teacher communication.

OBE needs online courses and innovative teaching mode

Overall introducing online courses and enriching online resources can meet research-based teaching, case-based teaching and experience-based teaching, enhance students preview, before-class learning organization, online doubt answering, online discussion and online test, enhance interactions and solve the defects of traditional teaching and also provide basis for formative evaluation. Under the long-term cramming teaching method, students' autonomous learning ability is low and their motivation for autonomous learning is seriously insufficient. As a result, students' information retrieval capability, team cooperation and communication ability as well as innovation ability are difficult to meet the training requirements of engineering major. The lifelong learning ability of the students trained under the traditional mode is not properly trained.

\section{Online course construction}

To construct online courses supporting teaching, first of ally, a system platform with powerful functions is required to support course construction, online teaching, online test and online statistics etc. Besides, it should achieve seamless joint with campus network portal and allow one-stop login for students and teachers. Teaching interaction platform must regard courses as the center and offer all-round network teaching functions, including assignment, quiz, notice, doubt answering, discussion, data and evaluation etc. Through statistics of data in the teaching process, comprehensive and visual statistic analysis can be made for teaches' teaching, students' learning and course visit so as to help teachers and schools better carry out teaching management estimation.

Apart from a good platform, superior online courses are also required. It is required to value frame system construction for online courses, guide teachers to reshape course structure and enrich course resources according to features of different courses and online courses. Meanwhile, six functional modules should be established, including key and difficult points, teaching courseware, teaching video, basic concepts and terms, online test and extended material. With regard to course resources, interesting, cutting-edge, innovative and extended readings should be added. Teaching video should pave the way for teaching content and enhance relevance between knowledge points. Besides, professional knowledge should be popular, and self-learners' learning situation should be improved.

\section{Course system design under the background of modern information technology}

About the blended learning based on online and offline courses, flipped classroom is a really effective method. In other words, students first learn and teaches teach them. Such teaching mode can let students improve comprehensive quality in many aspects (such as autonomous learning, language expression, teamwork, data collection and organization, and PPT making), and learn courses deeply and widely. But it cannot be denied that in the flipped classroom, students will put more energy. It cannot be imagined and is also infeasible to carry out the flipped classroom for many courses. In the face of such contradiction, the solution is to take into account of flipped classroom setting from the perspective of Top-level Design, carefully investigate each course in the training program and seek the courses suitable for flipped classroom and the teachers with ability and experience who are willing to put themselves into the flipped classroom and adapt to the development of modern education technology. These courses should cover public elementary courses, professional elementary courses and professional courses. Besides, the flipped classroom should cover other 7 semesters, except the last semester. Two courses may be chosen for flipped classroom in each semester, and the rime should be staggered. Small class teaching should be arranged for flipped classroom.

On this basis, training program, teaching method of single course and student evaluation deign are fused, and the top-level design based on major training scheme which the course serious with inverse 
design and positive implementation as one body and online course (all courses) and flipped classroom (some courses) as the two wings is proposed. Online courses provide mass resources and support diversified teaching mode and lifelong learning platform. The flipped classroom train students' personality development, teamwork, basic skills and learning behaviors from teaching perspective, changes passive study to active study and alters teachers' teaching behaviors.

\section{Practice and summary}

\section{Online course construction and application}

In September 2014, individual interactive teaching platform - "Hehai Course Online" was launched formally. The platform reflects future development trend of online education, with good stability, strong adaptability and good usability. It covers the whole process of learning and carries out all-round data connection, analysis and monitoring for each link such as video, data sharing, assignment, question answering, question asking and examination, and achieves scientific evaluation of teaching effect and teaching organization. The platform gives full play to the function of modern information technology, advocates heuristic, inquiry-based, discussion-based and participative teaching and trains students' learning interest and autonomous learning ability.

Hydraulic and Hydropower Engineering major is taken for example. 23 three-level online courses (university, province and nation) were constructed, including public required courses (Basic Principle of Marxism and College English etc.), subject platform courses (Higher Mathematics, Mechanics of Materials and Foundation of Engineering Drawing etc.), professional basic courses (Introduction to Civil and Hydraulic Engineering, Hydraulics and Reinforced Concrete Structure etc.) and professional courses (Hydraulic Structure, Hydropower Station and Engineering Construction etc.). The courses account for $65.7 \%$ of required courses. The platform well supported various blended teaching methods (online, offline and classroom). In particular, flipped classroom was carried out for 6 courses or some of them. Teachers and students exchanged and discussed actively, which promoted the improvement of in-depth study and autonomous learning ability. Teachers also benefited a lot. All these courses introduced multirole evaluation methods which combine formative evaluation and summative evaluation, and focused on students' learning process. Formative evaluation data would be published regularly to guide students to keep improving learning method and enhancing learning consciousness and to form the virtuous circle. The GPAs of Hydraulic Engineering majors in 2014 and 2013 in the first 5 semesters were compared. It can be seen from the comparison that, the majors in 2014 improved a lot after blended teaching and formative evaluation.

Table 1. Comparison of GPAs of Hydraulic Engineering majors in 2014 and 2013

\begin{tabular}{|c|c|c|c|c|c|}
\hline Grade & $\begin{array}{c}\text { 1st semester of } \\
\text { freshman year }\end{array}$ & $\begin{array}{c}\text { 2nd semester of } \\
\text { freshman year }\end{array}$ & $\begin{array}{c}\text { 1st semester of } \\
\text { sophomore year }\end{array}$ & $\begin{array}{c}\text { 2nd semester of } \\
\text { sophomore year }\end{array}$ & $\begin{array}{c}\text { 1st semester of } \\
\text { junior year }\end{array}$ \\
\hline $\begin{array}{c}\text { GPA of Hydraulic } \\
\text { Engineering majors in } \\
2013\end{array}$ & 3.91 & 3.64 & 3.61 & 3.69 & 3.72 \\
\hline $\begin{array}{c}\text { GPA of Hydraulic } \\
\text { Engineering majors in } \\
2013\end{array}$ & 4 & 3.58 & 3.54 & 3.88 \\
\hline $\begin{array}{c}\text { Increased or decreased } \\
\text { percentage of majors in } \\
\text { 2014, compared with the } \\
\text { majors in 2013 }\end{array}$ & $2.30 \%$ & $-1.65 \%$ & $-1.94 \%$ & $5.15 \%$ & $3.76 \%$ \\
\hline
\end{tabular}

\section{Summary}

OBE owns three core ideas: student-centered, inverse design and continuous improvement. Student-centered idea runs through the whole process from top-level design to course teaching. Students can really change passive study to active study and cultivate creative and critical thinking as well as problem-solving ability only when the following points are done: changing existing 
traditional teaching mode, actively carrying out teaching practice and exploration which deeply fuses online, offline and classroom based on online courses, focusing on students' individual differences, and giving students continuous evaluation in the whole course teaching process.

The effect of inverse design and positive implementation depends on teachers' professional level, teaching level and teaching input. Changing the teaching mode and grasping modern educational technology are the inevitable way to carry out student-centered teaching and also the precondition of effective implementation of formative evaluation. Student-centered teaching will put forward higher requirements and more challenges to teachers.

\section{Acknowledgements}

Jiangsu University Brand Specialty Building Fund (Class A, S/N PPZY2015A043).

\section{References}

[1] Jiang Bo, OBE:Outcome-Based Education, Studies In Foreign Education, 2003(3):35-37.

[2] Gu Peihua, Hu Wenlong, Lin Peng, Bao Nengsheng, Lu Xiaohua, Xiong Guangjing, Chen Yan, OBE Engineering Education Model in Shantou University, Research in Higher Education of Engineering, 2014(1):27-37.

[3] Li Zhiyi, Zhu Hong, Lu Zhijun, Xia Yuanjing, Guiding the Reform of Higher Engineering Education with Result-oriented Educational Ideas, Research in Higher Education of Engineering, 014(2):29-34+70.

[4] Wu Yalin, Interpretation of Student-Centered Educational Idea, Educational Review, 2005(4):21-23.

[5] Li Zhiyi, Interpretation of Student-centered Idea in Engineering Education Specialty Certification, China Higher Education, 2014(21):19-22.

[6] Zhu Huaixin, Mao Hongxia, A Probe into the Curriculum Model of Outcomes-Based Education(OBE) in South Africa, Studies in Foreign Education, 2006(4):34-38. 